\title{
'This is not who we are': Gendered bordering practices, ontological insecurity, and lines of continuity under the Trump presidency - CORRIGENDUM
}

\author{
Christine Agius* \\ Department of Humanities and Social Sciences, School of Social Sciences, Media, Film and Education, Swinburne University \\ of Technology, Hawthorn, Melbourne, Australia \\ ${ }^{*}$ Corresponding author. Email: cagius@swin.edu.au
}

(First published online 7 January 2022)

doi:10.1017/S0260210521000590, published online by Cambridge University Press, 04 November 2021.

Keywords: Ontological Security; Gender; Bordering; Trump; Gender; Security/War Studies

The author has noticed a mistake in the Abstract and would like to rectify this to read as follows:

The Trump presidency ushered in a heightened sense of ontological insecurity in the US, based on a national self-narrative that portrayed an emasculated America. Trump promised to return the US to primacy by pursuing policies and practices that focused on border protection, militarisation, and the vilification of external others, while amplifying racial tensions within the country. From caging immigrant children at the border, to an enabling of white supremacy and the Capitol riots, Trump's presidency was broadly seen as aberration in the self-narrative of America as a tolerant, democratic nation. In this article, I am interested in how gendered bordering practices inform ontological (in)security in Trump's narrative of the nation, domestic and external policy, and discourses. While Trump's electoral loss to Biden in 2020 has been described as a 'return to normal', this article instead considers how Trump's presidency exhibited lines of continuity when examined through a gender lens. Understanding how masculinism informs ideas of ontological security reveals how notions of gendered bordering, hierarchy, and ordering have been persistent threads in US politics, rather than simply an anomaly under Trump. This suggests greater potential to read ontological security in more complex terms through gendered bordering practices.

The author also noticed the following mistakes in the references:

Footnote 14 should read as follows: Lucy Nicholas and Christine Agius, The Persistence of Global Masculinism: Discourse, Gender and Neo-Colonial Re-Articulations of Violence (Cham, Switzerland: Palgrave, 2018), p. 8.

In footnote 21, Anthony Giddens was misspelt as Antony Giddens.

The author apologises for these errors. 


\section{Reference}

Agius, C. (2021). 'This is not who we are': Gendered bordering practices, ontological insecurity, and lines of continuity under the Trump presidency. Review of International Studies, 1-18. doi:10.1017/S0260210521000590

Cite this article: Agius, C. 2022. 'This is not who we are': Gendered bordering practices, ontological insecurity, and lines of continuity under the Trump presidency - CORRIGENDUM. Review of International Studies 48, 403-404. https://doi.org/ $10.1017 /$ S026021052100067X 